\title{
Intrahousehold Bargaining Power in Spain: An Empirical Test of the Collective Model
}

\author{
José Alberto Molina ${ }^{1,2,3}\left[\right.$. Jorge Velilla ${ }^{1,2}\left(\mathbb{D} \cdot\right.$ Helena Ibarra $^{1}$
}

Accepted: 21 November 2021 / Published online: 3 January 2022

(c) The Author(s) 2022

\begin{abstract}
This paper analyzes the intrahousehold bargaining power of spouses in Spanish families, in a collective framework. We estimate household labor supply equations and, under certain testable restrictions, we obtain a theoretically derived sharing rule for household income, which characterizes intrahousehold bargaining power. Then, using unique data on decision-making in the household, we construct Pareto weights, and study the validity of the collective model by comparing the theoretical sharing rule and the constructed Pareto weight. The results reveal that both the observed Pareto weight and the theoretical sharing rule display qualitative similarities, thus providing direct empirical support to the collective model. Furthermore, the results suggest that Spanish wives behave more altruistically, while husbands behave more egoistically. This should be taken into account by policy makers and researchers when analyzing inequality in the household, and contemplating specific policies affecting the household.
\end{abstract}

Keywords Collective model $\cdot$ Labor supply $\cdot$ Intrahousehold bargaining power $\cdot$ Spain

JEL Codes D13 $\cdot$ J22

\section{Introduction}

This paper analyzes intrahousehold decision making in Spanish families, in order to identify the bargaining power of spouses. To that end, it follows the collective model of labor supply (Chiappori et al., 2002), which assumes that household members cooperate to reach Pareto-efficient outcomes. The study provides a direct estimate of intrahousehold bargaining power from unique data on intrahousehold decisions, which serves as a test for the validity of the collective framework. Studies of inequality often ignore an important aspect that emerges from the intrahousehold allocation of resources, which can lead to an incomplete view of the situation (Chiappori \& Meghir, 2015; Radchenko, 2016).

Jorge Velilla

jvelilla@unizar.es

1 Department of Economic Analysis, University of Zaragoza, C/ Gran Vía 2, 50005 Zaragoza, Spain

2 IEDIS, University of Zaragoza, C/ Gran Vía 2, 50005 Zaragoza, Spain

3 IZA, Schaumburg-Lippe-Straße 5-9, 53113 Bonn, Germany
Inequality may increase if resources within the household are allocated in such a way that endowment differences are reinforced, while inequality may decrease if those differences are taken into account. Thus, the analysis of the spouse's intrahousehold share of resources is important for the design of policies aimed at alleviating poverty.

Prior to the 1980s, 'the family' had primarily been studied by following a "unitary" approach, where households were seen as units with a single utility function, which was essentially equivalent to considering them as 'black boxes'. This unitary approach gave rise to certain difficulties, including the lack of theoretical foundations and non-convincing empirical results (e.g., Duflo, 2003; Lundberg et al., 1997; Thomas, 1990). In the early 1980s, motivated by the work of Gary Becker (Becker, 1991), several approaches were developed to analyze the intrahousehold decision process. A variety of models emerged, viewing household processes as cooperative games (Bargain \& Moreau, 2013; Manser \& Brown, 1980; McElroy \& Horney, 1981), non-cooperative games (Bergstrom, 1997; Lundberg \& Pollak, 1994), independent individual models (Grossbard-Shechtman, 1984), and household social welfare programs (Chiappori, 1988, 1992). Among these, a number of empirical applications 
rely on the so-called "collective" model, first proposed by Chiappori (1988, 1992). Browning and Chiappori (1998) then introduced the concept of "distribution factors", and Chiappori et al. (2002) developed a general collective model of labor supply, including distribution factors, along with an empirical estimate of the model in the US, which provided indirect evidence on how spouses share their resources within households, through theoretically derived sharing rules. The collective model has become one of the main frameworks used in the study of family behaviors, and several authors have demonstrated the validity of the approach, against the traditional unitary approach (e.g., Attanasio \& Lechene, 2014; Giovanis \& Ozdamar, 2019; Lyssiotou, 2017; Rapoport et al., 2011) See the surveys by Donni and Chiappori (2011), Chiappori and Mazzocco (2017), and Donni and Molina (2018), while details on the theoretical foundations and empirical specifications related to the collective models are shown in Browning et al. (2014).

The collective model addressed several of the problems of the unitary approach, derived from the fact that the family is considered as a black box, and household formation and/ or dissolution is not considered. In this context, the unitary approach imposes a series of restrictions on observed behavior, which include that it does not allow for the establishment of the intrahousehold distribution of consumption, nor of productive resources, and consequently, of intrahousehold well-being. This produces biased estimates of intrahousehold inequality (Browning et al., 2013; Dunbar et al., 2013). But the latter consideration allows researchers to use the collective model to study wealth, welfare, and inequality within families. Thus, the collective model of household behaviors seems to be the ideal tool with which to examine how households allocate their resources, their income, and their welfare (Chiappori \& Mazzocco, 2017). Nevertheless, the collective model remains a theoretical tool, as it allows researchers to analyze spouses observed behavior and, if such behavior is compatible with certain testable restrictions, the distribution of power within the household (and thus the allocation of resources) can be theoretically derived from the observed behaviors. In this context, however, few authors have directly estimated intrahousehold bargaining power-a difficult task, given that this power is by definition unobservable - which would give empirical support to the main theoretical conclusions derived from the collective model. ${ }^{1}$

Despite that, and setting aside the unitary approach, several authors have studied family decision making under

\footnotetext{
${ }^{1}$ Bargain et al. (2018) provided direct evidence in line with the predictions of the collective model using data on sharing in Bangladesh, and Velilla (2020) analyzed the empirical validity of the sharing rule in a discrete choice mode, using data from employed husbands and unemployed wives in Spain.
}

different bargaining frameworks (Yusof \& Duasa, 2010). A commonality of bargaining models of household decision making is that they consider different and possibly conflicting preferences of family members (usually spouses), who then bargain to reach household decisions. Such a bargaining process, similar to the collective model, are governed by the notion of power in the household, determined by observables such as relative income, unearned income, human capital, and labor supply (Jianakoplos \& Bernasek, 2008; Malone et al., 2010; Yilmazer \& Lyons, 2010). Some specific household decisions that have been recently studied include financial decisions (Lim et al., 2021), work-family decisions (Molina, 2021), consumption (Chiappori \& Naidoo, 2020; Lien et al., 2018), commuting trips (Carta \& De Philippis, 2018), fertility (Pronzato, 2017), and entrepreneurial decisions (Bettinelli et al., 2017), among others. See Chiappori (2020) and Chiappori and Meghir (2021) for a recent review of household economic behaviors, the marriage market, and family decision making.

Against this background, the objective of this paper is to study intrahousehold bargaining power in Spain, based on a collective model of household labor supply. Using data from the European Union Statistics on Income and Living Conditions, we estimate spouses labor supply equations, as proposed by Chiappori et al. (2002), and then derive the theoretical sharing rule of household income from those estimates, characterizing intrahousehold bargaining power and resource allocation. Using unique information from the 2010 module on intrahousehold sharing of resources, we then construct a variable that accounts for bargaining power in the household, and compare whether the theoretical sharing rule is compatible with estimates on that constructed proxy for bargaining power. This allows us to test the collective model of labor supply and, in particular, the characterization of bargaining power in the household derived from that model. The results indicate that the sharing rule theoretically derived from spouses' labor supply estimates is compatible with similar estimates on the constructed indicator of intrahousehold bargaining power, which gives empirical support to the collective model.

The contributions of the paper are twofold. First, we empirically study spousal labor supply, and derive a theoretical sharing rule of household income that allows us to analyze the intrahousehold allocation of resources in Spanish households, in terms of individual wages and non-labor income. Our estimates reject the unitary model, and are in line with the predictions of the collective model, suggesting that spouses behave cooperatively. Furthermore, we find that wives behave altruistically, while husbands are more egoistic, since the sharing rule estimates suggest that, for each additional Euro earned by the wife (husband), the wife retains 0.4 Euros (0.14 Euros). Second, we perform an empirical test on household collective models of labor 
supply, using data for Spain, thus complementing existing research for the case of developing economies (Bargain et al., 2018). The results indicate that intrahousehold behaviors and resource allocation in Spain are compatible with the predictions of the collective model, as estimates of the constructed bargaining power index, and estimates of the theoretically derived sharing rule, both measuring intrahousehold sharing, are qualitatively robust.

\section{Theoretical Framework}

The general collective model has evolved in recent decades to include, for example, public commodities (Blundell et al., 2005; Chiappori \& Weiss, 2007), participation in employment (Blundell et al., 2007), domestic production (Browning et al., 2013), and time dimensions (Chiappri et al. 2020; Lise \& Yamada, 2019; Mazzocco, 2007). In this section, we provide a brief summary of the simplest version of the collective model of labor supply with distribution factors, as proposed by Chiappori et al. (2002).

We assume that households consist of two spouses, $i=1,2$, with distinct preferences and individual utility functions, $U^{i}=U^{i}\left(1-h^{i}, C^{i}, z\right)$, where $h^{i} \in(0,1)$ represents paid work time of spouse $i$, so $1-h^{i}$ represents private leisure. $C^{i}$ represents the private consumption of a Hicksian good with unitary price, and $z$ represents a vector of preference factors. The utility functions are assumed to satisfy a set of required properties, i.e., they are strictly quasi-concave, increasing, and continuously differentiable. The main hypothesis of the collective model is that spouses know each other's' preferences, and that the household decision process leads to a Pareto-efficient outcome (Chiappori, 1988, 1992). Assuming Pareto efficiency requires that the outcome chosen by household members cannot be improved upon, in the sense that no alternative allocation would be unanimously preferred by household members. This assumption is not especially restrictive in a static framework, as it refers to the ability of spouses to be aware of the preferences of each other (even when individual preferences are egoistic), and act cooperatively to take advantage of marriage.

Under these hypotheses, the allocation of resources in the household is fully determined by the spouses' bargaining power in household decision-making. Then, there exists a Pareto weight, which is unobserved but depends on observable factors, $\mu=\mu\left(w_{1}, w_{2}, y, \mathbf{z}, s\right) \in(0,1)$, such that the household solves Program:

$\max _{\left\{h^{1}, h^{2}, C^{1}, C^{2}\right\}} \mu U^{1}+(1-\mu) U^{2}$

subject to the budget constraint: $w_{1} h^{1}+w_{2} h^{2}+y=C^{1}+C^{2}$

In this setting, $w_{i}$ represents spousal wages, $y$ represents household non-labor income, and $s$ is a vector of distribution factors, which are variables that affect intrahousehold decisions and the Pareto weight, but not individual preferences (Browning \& Chiappori, 1998; Chiappori et al., 2002). See Browning et al. (2014) for details on the collective model in a more generalized setting.

It is well-established that the problem $\left(\mathrm{P}_{1}\right)$ is equivalent, on the basis of the Second Fundamental Welfare Theorem, to a decentralized two-stage process where, first, household members negotiate the allocation of household income, according to a "sharing rule", $\phi=\phi(\mu)$, such that agent 1 receives $\phi_{1}=\phi$, and agent 2 receives $\phi_{2}=y-\phi$. See a formal demonstration in Chiappori (1992). Each spouse $i$ solves the individual Program:

$\max _{\left\{h^{i}, C^{i}\right\}} U^{i}\left(1-h^{i}, C^{i}, \mathbf{z}\right)$ $\left\{h^{i}, C^{i}\right\}$

subject to the budget constraint:

$w_{i} h^{i}+\phi_{i}(\mu)=C^{i}$

Then, the solution of the household problem can be expressed as the solution of the initial Program or, equivalently, as the solution of the pair of individual Programs subject to the sharing rule. That is to say, spouses' labor supply equations, as the solution of the household program, must be the same equations as the solutions of the individual programs:

$h^{1}\left(w_{1}, w_{2}, y, \mathbf{z}, s\right)=H^{1}\left(w_{1}, \phi\left(w_{1}, w_{2}, y, \mathbf{z}, s\right), \mathbf{z}\right)$,

$h^{2}\left(w_{1}, w_{2}, y, \mathbf{z}, s\right)=H^{2}\left(w_{2}, y-\phi\left(w_{1}, w_{2}, y, \mathbf{z}, s\right), \mathbf{z}\right)$

where $H^{i}$ denotes individual $i$ 's Marshallian demand, i.e., the solution to Eqs. (3) and (4). Using these equations, Chiappori et al (2002) generated a set of testable restrictions that must be satisfied for the equations to be the solution of both Program (1) and Program (3). If such restrictions are satisfied, they define a system of partial derivatives of the unobservable sharing rule equation, in terms of derivatives of spouses' labor supply equations. By solving the system of partial derivatives, one can recover, either in general terms or under a given functional form of spouses' labor supply equations, the sharing rule of household income, $\phi$, up to an integration constant. Given that the sharing rule is oneto-one related to the spouses' bargaining positions, as represented by the Pareto weight, the collective model allows the study of intrahousehold decision-making through observed behavior. See the mathematical details in Browning et al. (2014). 
Let us assume, without loss of generality, that spouse 1 refers to the wife, and spouse 2 refers to the husband. We then follow prior analyses by Campaña et al. (2018), Chiappori et al. (2002), Lyssiotou (2017), and Rapoport et al. (2011), and specify the usual semi-log parametric form of individual labor supply equations:

$h^{1}=f_{0}+f_{1} \log w_{1}+f_{2} \log w_{2}+f_{3} y+f_{4} \log w_{1} \log w_{2}+f_{5} s_{1}+f_{6} s_{2}+f_{7} z$

$$
\begin{aligned}
h^{2}= & m_{0}+m_{1} \log w_{1}+m_{2} \log w_{2}+m_{3} y \\
& +m_{4} \log w_{1} \log w_{2}+m_{5} s_{1}+m_{6} s_{2}+\boldsymbol{m}_{7} \boldsymbol{z}
\end{aligned}
$$

Then, if $\frac{m_{3}}{f_{3}} \neq \frac{m_{5}}{f_{5}}$, it is possible to find a set of partial derivatives of the sharing rule that produce the following expression of the sharing rule,

$$
\begin{aligned}
\phi= & \frac{1}{\Delta}\left(m_{1} f_{4} \log w_{1}+f_{2} m_{4} \log w_{2}+f_{3} m_{4} y+f_{4} m_{4} \log w_{1} \log w_{2}\right. \\
& \left.+m_{4} f_{5} s\right)+\kappa(z)
\end{aligned}
$$

which is valid if and only if $\frac{m_{4}}{f_{4}}=\frac{m_{5}}{f_{5}}=\frac{m_{6}}{f_{6}}$, where $\Delta=f_{3} m_{4}-f_{4} m_{3} \neq 0$, and $\kappa(\mathbf{z})$ represents the integrating constant.

\section{The Intuition of the Model}

All in all, the intuition behind the collective model is as follows. Assuming only that spouses cooperate to reach Pareto efficient outcomes, one can characterize household observed behaviors, such as consumption or, in this particular case, spouses' labor supply, in a collective context. Then, recasting the second welfare theorem, the model can be decomposed into a two-stage individual process in which each spouse's labor supply is individually characterized. This produces two solutions to the collective program per spouse, which should be equivalent, provided that the household behaves as assumed (i.e., provided that spouses cooperate). By combining the two pairs of solutions of the household problem, one can theoretically recover how the household allocates its resources between spouses, which is equivalent to the characterization of spouses' power in household decision making.

From a practical perspective, the collective model allows us to analyze household observed behaviors, such as labor supply (which is commonly collected in databases). Then, conditional on the household behaving as assumed by the collective model (i.e., if the labor supply equations satisfy a series of testable conditions), one can theoretically derive a series of parameters from the labor supply equations that identify the unobserved intrahousehold allocation of income and, thus, spouses' unobserved bargaining powers. Despite the relevance of the model in this context, it should be noted that intrahousehold allocations can only be indirectly studied under such a setting, as they can only be theoretically recovered from labor supply equations. In such a context, the main contribution of this paper is using unique data on household decision making to directly study spouses' power in the household, to compare such estimates to the theoretically derived allocation of resources in the household, and thus provide a test of the collective model of labor supply in its simplest, general version.

\section{Data}

We use data from the European Union Statistics on Income and Living Conditions (EU-SILC), restricted to individuals residing in Spain. The EU-SILC data is a comparable and multidimensional microdata, and is part of the European Statistical System. It is conducted every year by Eurostat (since 2003), and includes both longitudinal and cross-sectional samples, though these are not comparable (e.g., individuals in the cross-sectional samples, for whom there is information from the different Special Modules, do not belong to the longitudinal sample). The EU-SILC provides information at the family and individual level for interviewed households, and covers a range of factors, including income, labor characteristics, poverty, and living conditions, among others (European Commission, 2017). Specifically, we retain individuals who completed the Special Module on Intrahousehold Sharing of Resources of the year 2010, which is restricted to the cross-sectional sample. This Special Module is intended to provide deeper insights into the decision-making process within households, understand the allocation of resources within the household, and address intrahousehold inequality and standards of living (European Commission, 2010).

The sample is restricted to those Spanish households formed by a "wife" and a "husband" (whether married or unmarried), which is consistent with the definition of marriage in Grossbard (2014). Furthermore, given the theoretical context, we retain spouses who report positive hours of work, as in Chiappori et al. (2002). These restrictions lead to a sample of 2726 households, each formed by a working wife and a working husband. Given that the Special Module is only filled-in by the core EU-SILC respondents who are between 22 and 65 years old (inclusive), we do not need to apply any age restriction that minimizes the role of time allocation decisions over the life cycle (Aguiar \& Hurst, 2007; Gimenez-Nadal \& Sevilla, 2012).

The primary variables that we define from the main analysis are spouses' hours of work, spouses' earnings, and household income. First, spouses' hours of work are defined 
in the EU-SILC data as weekly work hours. ${ }^{2}$ Second, we define spouses labor earnings as their respective annual earnings, net of taxes, that is, the sum of individual sources of labor income (net cash plus non-cash individual income from labor, plus net self-employment benefits in the case of self-employed workers). Third, the EU-SILC includes information on the annual (total) disposable income of households, defined as the sum for all household members of personal income components (cash or near cash income, company car, cash benefits or losses from self-employment, pensions received from individual private plans, unemployment benefits, old-age benefits, survivor benefits, sickness benefits, disability benefits, education-related allowances, income from rental of a property or land, family/childrelated allowances, social exclusion not elsewhere classified, housing allowances, inter-household cash transfers, interest, dividends, profit from capital investments in unincorporated business, and income received by individuals under age 16), net of taxes. ${ }^{3}$

In addition to these main variables, the EU-SILC allows us to define a series of spousal sociodemographics. (1) The age of spouses, measured in years. (2) The maximum education level achieved by spouses, defined in terms of the International Standard Classification of Education (ISCED). Two dummies are defined: University education, that takes value 1 if individuals have reached University ( 0 otherwise); and secondary education, that takes value 1 if individuals have reached secondary, non-compulsory education ( 0 otherwise). Thus, the reference group for education corresponds to low-educated individuals who have not reached non-compulsory education. (3) The number of children present in the household. (4) A dummy variable that takes value 1 for those couples who are legally married, 0 for unmarried but cohabiting couples. (5) A variable that measures the length of the marriage, measured in years, and taking value 0 for cohabiting but unmarried couples. (6) Dummies for the region of residence of individuals, to account for potential by-region differences.

Summary statistics of the variables are shown in Table 1. The average weekly work hours of wives are $35.5 \mathrm{~h}$, vs $42.7 \mathrm{~h}$ worked per week by the average husband. The average wife earnings are $€ 20,350$ per year, vs $€ 28,444$ per year earned,

\footnotetext{
2 Chiappori et al. (2002) run the test on annual hours of work, as that is the information included in their data (the Panel Study of Income Dynamics of the US). As the EU-SILC covers only weekly hours of work, we decided to work with that variable. Defining annual hours of work in terms of weekly hours of work would suppose an algebraic change that should not affect the results.

3 The annual (total) disposable income of households is converted to household non-labor income by dropping the labor earnings components. Negative values are allowed, representing losses from assets, debt, or negative household gains.
}

Table 1 Summary statistics

\begin{tabular}{lll}
\hline Variables & $(1)$ & $(2)$ \\
& Mean & S.Dev \\
\hline Wife variables & & \\
Work hours & 35.512 & 9.924 \\
Earnings/1000 & 20.350 & 16.097 \\
Age & 42.641 & 8.449 \\
Secondary ed & 0.230 & 0.421 \\
University ed & 0.484 & 0.499 \\
Husband variables & & \\
Work hours & 42.739 & 8.041 \\
Earnings/1,000 & 28.444 & 24.131 \\
Age & 44.754 & 8.766 \\
Secondary ed & 0.255 & 0.436 \\
University ed & 0.402 & 0.490 \\
Distribution factors & & \\
Wife share of family income & 1.021 & 0.031 \\
Sex ratio & 0.012 & 0.043 \\
Household variables & & \\
Family income/1,000 & 45.576 & 25.577 \\
Number of children & 0.519 & 0.787 \\
Legally married & 0.871 & 0.334 \\
Length of marriage & 16.399 & 9.574 \\
Observations & 2726 & \\
\hline
\end{tabular}

The sample (EU-SILC 2010 module on intrahousehold sharing of resources) has been restricted to working spouses (married and unmarried)

on average, by husbands. The average ages are 42.6 years for wives, and 44.8 years for husbands, while $23.0 \%$ of wives and $25.5 \%$ of husbands have secondary education, vs $48.4 \%$ and $40.2 \%$, respectively, with University education. The average household has a total disposable income of about $€ 45,576$ per year, and has 0.5 children. Finally, $87.1 \%$ of the households are formed by legally married spouses, with an average marriage duration of 16.4 years.

\section{Distribution Factors}

Taking into account the theoretical framework proposed by Chiappori $(1988,1992)$, and in particular the model developed by Chiappori et al. (2002), we include in the analysis two distribution factors, that is to say, two variables that affect the spouses' bargaining power in the household, but do not affect individual preferences and the budget constraint. For instance, we consider two prominent distribution factors, which are the sex ratio and the share of female non-labor income over family income (Browning et al., 2014; Campaña et al., 2018; Chiappori et al., 2002; Molina et al., 2018).

The intuition of these distribution factors is as follows. On one hand, the sex ratio is considered a proxy for the 
relative supplies of women and men in the marriage market, so when it is favorable to women (when there are relatively more men than women and the sex ratio increases, thus representing a scarcity of women), wives should attract a larger fraction of household resources, representing an increase in the Pareto weight. On the other hand, when the share of wives' non-labor income increases, the wife's contribution to household non-labor income increases, and then she should also attract a larger fraction of household resources, driven by an increase in the Pareto weight.

Sex ratios are taken from the Spanish National Statistics Office (the Instituto Nacional de Estadística, INE), defined as masculinity indices (i.e., males per 100 females), by region and age group, and are matched to spouses in the sample, accounting for the age of the husband, and the region where the couple resides. Regarding the share of wives' non-labor income, it is defined as the rate of wives' non-labor income, over the household total income.

\section{The Constructed Bargaining Power}

The 2010 Special Module on Intrahousehold Sharing of Resources includes a series of items that may be used to build up a proxy for the bargaining power of wives within households. Thus, we consider the responses to these items by wives in the sample, and use these responses to run a Principal Components Analysis (PCA) and define a "constructed Pareto weight" as the output of the PCA. The items included in the questionnaire are as follows:

1. Decision-making on every day shopping: Thinking of you and your spouse or partner, who is more likely to take decisions on everyday shopping? (1 "more me", 0 "balanced", -1 "more my partner").

2. Decision-making on expensive purchases of consumer durables and furniture: Thinking of you and your spouse or partner, who is more likely to take decisions on expensive purchases of consumer durables and furniture? (1 "more me", 0 "balanced", - 1 "more my partner").

3. Decision-making on borrowing money: Thinking of you and your spouse or partner, who is more likely to take decisions on borrowing money? (1 "more me", 0 "balanced", -1 "more my partner").

4. Decision-making on use of savings: Thinking of you and your spouse or partner, who is more likely to take decisions on the use of savings? (1 "more me", 0 "balanced", -1 "more my partner").

5. Decision-making general: Thinking of you and your spouse or partner who is, on the whole, more likely to have the last word when taking important decisions? (1 "more me", 0 "balanced", -1 "more my partner").
6. Ability to decide about expenses for your own personal consumption, your leisure activities and hobbies: Do you feel free (i.e. without asking the permission of other household members) to spend money on yourself for your personal consumption, your leisure activities and hobbies? (1 "yes", 0 "sometimes", - 1 "never").

We have first analyzed whether it is suitable to run a PCA on these items. We estimate a Kaiser-Meyer-Olkin (KMO) value of 0.813 , which points to the PCA being appropriate in this context. Further, we have computed the Bartlett's Sphericity test, to study whether the correlation matrix of the items is the identity matrix. We reject the null hypothesis at standard levels $(p<0.001)$, which points to the existence of correlations among the items, thus suggesting that the PCA is appropriate.

We then run the PCA, and find that these six items can be merged into a single factor, with an eigenvalue greater than unity at standard levels. We also find a second factor for which the point estimate of the eigenvalue is greater than unity, but not at statistical standard levels, and we thus discard it. The scree plot of the PCA is shown in Figure 1 in the Appendix, and the loadings that define the factor, in terms of the initial survey items, are shown in Table 4 in the Appendix. All the loadings are positive, indicating that positive values of the initial items correlate to positive values of the defined factors. Given the values that take the initial items, factor loadings in Table 4 suggest that the constructed Pareto weight is identified by increases in the decision-making power of the wife, in all the dimensions considered, and thus the factor represents the bargaining power of the wife, that is to say, the Pareto weight $\mu$ as defined in the model.

\section{Results}

We first estimate Eqs. (7) and (8) by Ordinary Least Squares, including region fixed effects and sample weights provided by the 2010 Special Module. The results are shown in Columns (1) and (2) of Table 5 in the Appendix, for wives and husbands, respectively. However, given that the error terms are potentially correlated when estimating spouses' labor supply equations, we re-estimate Eqs. (7) and (8) by a Seemingly Unrelated Regressions model, whose results are shown in Columns (1) and (2) in Table 2. As the main coefficients remain qualitatively unchanged, the results appear not to depend on potential correlation in the error terms of spousal hours of work.

We find that the wife's hours of work are negatively correlated with the husband's earnings, with the associated coefficient being statistically significant at standard levels, while the coefficient associated with the earnings of the wife is not statistically significant at standard levels. Contrarily, 
in the husbands' hours equation, both the wife's and the husband's earnings show negative and highly significant coefficients. This rejects the income-pooling property, according to which an extra Euro added to the family income should have a similar impact on spousal behavior, regardless of who earned that income. Therefore, by rejecting the income pooling property, the estimates in Table 2 reject the unitary model. The cross-log term is estimated to be positively correlated with both spouses' hours of work, and both coefficients are statistically significant at standard levels, while household income is statistically significant only for husbands, as it is negative and non-significant in the wives' equation. Focusing on the distribution factors, the share of wives' non-labor income is positive and highly significant for wives, but negative and non-significant at standard levels for husbands. Similarly, the sex ratio shows a negative and significant coefficient in the wives' equation, but a nonsignificant coefficient in the husbands.

SUR estimates do not seem to reject the collective rationality restriction, as the impact of distribution factors on wives' and husbands' observed behavior is different, as expected from the theory. Nevertheless, deriving a sharing rule equation from estimates, as proposed in Eq. (9), requires some specific constraints in the labor supply equations (e.g., the ratio of coefficients associated with cross-income, and with the distribution factors, should be similar). To address such constraints, we re-estimate Eqs. (7) and (8) using the Generalized Method of Moments (Hansen, 1982), and apply the restrictions imposed by the model to derive the sharing rule of non-labor income. In doing so, we use the GMM optimal weighting matrix and calculate asymptotic standard errors (Chiappori et al., 2020). ChiThe main results are shown in Columns (3) and (4) of Table 2, and the coefficients remain unchanged from SUR estimates, suggesting that imposing the theory restrictions does not distort spouses' labor supply estimates. Additional coefficients are shown in Table 5 in the Appendix.

Column (1) of Table 3 shows the associated coefficients of the theoretically-derived sharing rule, which is computed from the labor supply GMM estimates in Table 2, following Eq. (9). We find that the sharing rule of household income within the household is determined by spouses' earnings in a statistically significant way, while household income appears to be non-significant at standard levels. For instance, partial derivatives of the sharing rule with respect to spousal earnings reveal that, for each additional Euro earned by the wife, she retains 0.4 Euros for herself, while for each additional Euro earned by the husband, the wife retains only 0.14 Euros. This suggests that wives tend to behave altruistically (i.e., they share a large fraction of their additional income),
Table 2 Household labor supply estimates

\begin{tabular}{|c|c|c|c|c|}
\hline \multirow[t]{3}{*}{ Variables } & \multicolumn{2}{|c|}{ SUR unrestricted estimates } & \multicolumn{2}{|c|}{ GMM restricted estimates } \\
\hline & (1) & $(2)$ & (3) & (4) \\
\hline & Wives & Husbands & Wives & Husbands \\
\hline Wife log-earnings & $\begin{array}{l}0.756 \\
(0.728)\end{array}$ & $\begin{array}{l}-2.690 * * * \\
(0.617)\end{array}$ & $\begin{array}{l}0.251 \\
(0.719)\end{array}$ & $\begin{array}{l}-2.706^{* * *} \\
(0.591)\end{array}$ \\
\hline Husband log-earnings & $\begin{array}{l}-4.147 * * * \\
(0.661)\end{array}$ & $\begin{array}{l}-1.568 * * \\
(0.562)\end{array}$ & $\begin{array}{l}-5.074 * * * \\
(0.635)\end{array}$ & $\begin{array}{l}-2.333^{* * *} \\
(0.533)\end{array}$ \\
\hline Family income & $\begin{array}{l}-0.007 \\
(0.012)\end{array}$ & $\begin{array}{l}0.033 * * * \\
(0.010)\end{array}$ & $\begin{array}{l}0.020 \\
(0.012)\end{array}$ & $\begin{array}{l}0.043 * * * \\
(0.010)\end{array}$ \\
\hline Cross log-earnings & $\begin{array}{l}1.165 * * * \\
(0.234)\end{array}$ & $\begin{array}{l}0.393^{*} \\
(0.199)\end{array}$ & $\begin{array}{l}1.176 * * * \\
(0.226)\end{array}$ & $\begin{array}{l}0.417 * \\
(0.193)\end{array}$ \\
\hline Wife share of family income & $\begin{array}{l}14.200 * * * \\
(4.198)\end{array}$ & $\begin{array}{l}-5.602 \\
(3.576)\end{array}$ & $\begin{array}{l}6.433 \\
(4.210)\end{array}$ & $\begin{array}{l}-2.281 \\
(p=0.094)\end{array}$ \\
\hline Sex ratio & $\begin{array}{l}-0.642 * \\
(0.279)\end{array}$ & $\begin{array}{l}-0.152 \\
(0.238)\end{array}$ & $\begin{array}{l}-0.777 * * \\
(0.283)\end{array}$ & $\begin{array}{l}-0.276 \\
(p=0.215)\end{array}$ \\
\hline Constant & $\begin{array}{l}104.394 * * * \\
(28.617)\end{array}$ & $\begin{array}{l}66.496 * * \\
(24.376)\end{array}$ & $\begin{array}{l}121.566^{* * *} \\
(29.180)\end{array}$ & $\begin{array}{l}80.496 * * * \\
(17.919)\end{array}$ \\
\hline Sociodemographics & Yes & Yes & Yes & Yes \\
\hline Region F.E & Yes & Yes & Yes & Yes \\
\hline Observations & 2726 & 2726 & 2726 & 2726 \\
\hline
\end{tabular}

Robust standard errors in parentheses. The sample (EU-SILC 2010 module on intrahousehold sharing of resources) has been restricted to working spouses (married and unmarried). The dependent variables are spouses' log-weekly work hours. Columns (3) and (4) impose the restrictions described in the theory on distribution factors

${ }^{*} p<0.05 . * * p<0.01 . * * * p<0.001$ 
while husbands behave more egoistically (they share a small proportion of their additional earnings). Furthermore, regarding the distribution factors, the results indicate that the share of income which is wives' non-labor income is not statistically significant, while the sex-ratio (the number of males per 100 females) is correlated positively with the sharing rule, as predicted by the theory: when there are more males than females, and thus the conditions of the marriage market favor females, they attract a larger fraction of intrahousehold resources.

Column (2) of Table 3 shows estimates on the constructed Pareto weight. Given that the sharing rule of household income is a bijection of the Pareto weight, but expressed in Euros rather than in an abstract measure of bargaining power, one would expect that variables enter these estimates in a way similar to the way they entered the sharing rule equation in Column (1). The results reveal that this is exactly the case, as spouses' log-earnings enter the constructed Pareto weight equation positively, with both coefficients being statistically significant, while the cross-term is negative and also significant. On the other hand, the coefficient associated with household income is not significant at standard levels, and the sex ratio is positive and highly significant. The only qualitative difference between estimates in Columns (1) and (2) comes from the coefficient associated to the wife share of non-labor income, which is estimated to be negative and significant at the $90 \%$ level in Column (2), but not significant in Column (1). This suggests that, at least in the particular case of Spain, this variable is not a suitable distribution factor.

All in all, the results in Table 2 reject the unitary model of household behavior, and provide results compatible with the collective framework. Furthermore, Table 3 suggests that wives behave more altruistically, while husbands seem to behave more egoistically. Finally, estimates on the constructed Pareto weight are qualitatively similar to estimates of the theoretically-derived sharing rule of income, thus suggesting that the latter is a relatively fitted representation of how households behave. This gives direct empirical support to the collective model of labor supply, as the theoretical results are supported by unique data on decision-making within households.

\section{Discussion}

There are three main takeaways from the empirical analysis. First, the results suggest that Spanish households behave cooperatively, as the labor supply estimates are compatible with the collective model of labor supply. Furthermore, the results reject the unitary model, which assumes that the household behaves as a single unit regardless of its composition or potential differences between spouses' preferences.
Table 3 The sharing rule and bargaining power estimates

\begin{tabular}{lll}
\hline Variables & $\begin{array}{l}(1) \\
\text { Sharing rule of } \\
\text { family income }\end{array}$ & $\begin{array}{l}\text { Constructed } \\
\text { Pareto } \\
\text { weight }\end{array}$ \\
\hline Wife log-earnings & $2.830^{* * *}$ & $0.495^{* *}$ \\
& $(<0.001)$ & $(0.163)$ \\
Husband log-earnings & $1.881^{*}$ & $0.264^{*}$ \\
Family income & $(0.044)$ & $(0.127)$ \\
Cross log-earnings & -0.007 & 0.005 \\
& $(0.172)$ & $(0.003)$ \\
Wife share of family income & -0.436 & $-0.165^{* *}$ \\
Sex ratio & $(0.058)$ & $(0.055)$ \\
& -2.385 & -1.077 \\
Observations & $(0.211)$ & $(0.570)$ \\
\hline
\end{tabular}

P-values in parentheses in Column (1), and robust standard errors in parentheses in Column (2). The sample (EU-SILC 2010 module on intrahousehold sharing of resources) has been restricted to working spouses (married and unmarried). Coefficients in Column (1) are derived from estimates in Columns (5-6) of Table 3. The dependent variable is the constructed bargaining power in Column (2)

${ }^{*} p<0.05 .{ }^{* *} p<0.01 . * * * p<0.001$

Therefore, the empirical results are compatible with a context in which household members may have diverging preferences but cooperate to take advantage of the marriage, being aware of each other tastes and welfare. This result is in line with a number of prior studies on household collective behaviors in different countries, including Belgium (Vermeulen, 2006), Canada (Browning et al., 1994), France (Donni, 2007; Donni \& Moreau, 2007; Rapoport et al., 2011), Germany (Beblo et al., 2007; Beninger et al., 2006), the Netherlands (Cherchye \& Vermeulen, 2008; Cherchye et al., 2012; Vermeulen, 2005), Russia (Radchenko, 2016), the UK (Blundell et al., 2007; Lyssiotou, 2017; Myck et al., 2006), and the US (Cherchye et al., 2015; Chiappori et al., 2002; Donni \& Matteazzi, 2012, 2018; Michaud \& Vermeulen, 2011), among others. Furthermore, we complement prior studies of collective models in Spain (Crespo, 2009; Velilla, 2020).

Second, the labor supply equations allow us to theoretically derive the intrahousehold allocation of income. The sharing rule suggests that wives behave more altruistically, but the opposite behavior is found for husbands, given that for each additional Euro earned by the wife, she retains 0.4 Euros for herself, while for each additional Euro earned by the husband, the wife retains only 0.14 Euros. Third, the empirical results on the constructed powers in household decision-making are compatible with the theoretically 
derived sharing rule. That is to say, according to the results, intrahousehold behaviors of Spanish families, theoretically derived from the collective labor supply estimates, are in line with direct estimates on constructed power in intrahousehold decision making. This is the main contribution of the paper, as only a few prior analyses haved directly estimated the validity of the collective model (Bargain et al., 2018).

Future research should study the genesis of rational, collective behavior of households, along with potential reasons behind the differential behavior of spouses regarding intrahousehold sharing. Promising explanations for such differences may include social norms (Gimenez-Nadal et al., 2012), identity roles (Akerlof \& Kranton, 2010), or specific cultural dimensions in Spain (Guiso et al., 2006). ${ }^{4}$ For instance, several authors have established a link between culture, identity, and economic outcomes, including employment choices, preferences, education, and savings (Goldin, 2006; Guiso et al., 2006). Then, and especially among women, culture may explain earnings sharing (against husbands' egoism), along with other detrimental behaviors (Akerlof \& Kranton, 2000). In this sense, women may choose to behave altruistically because it is expected, and to avoid responses to husbands' behaviors (which are potentially egoistic). That is to say, under a potential positive earnings shock, women may choose to keep for themselves a small proportion of the extra income so that the traditional identity role of the husband as the main earner of the household prevails, while the opposite could operate among males. Existing research has concluded that altruism, cooperation, and collectivism are characteristic of Spanish individuals in different contexts, especially among relatives (Molina et al., 2019), and that women may be more likely to cooperate than men, especially when they cooperate with the partner (Görges, 2015). Similarly, other authors have reported gender differences in altruism and cooperation related to earnings (Cochard et al., 2018). Results in other countries (e.g., more individualistic countries, or developing economies) differ from the case of Spain. Cross-country comparative analyses may be especially useful in understanding how culture and social norms can affect intrahousehold issues.

\section{Conclusions}

This paper examines how spouses allocate their resources in Spain, following a collective approach that allows us to derive a sharing rule of non-labor income from household labor supply estimates. We then provide a direct test

\footnotetext{
${ }^{4}$ The empirical analysis of the link between household behaviors and a country's culture is beyond the scope of this paper, and is left for future research.
}

for the validity of the collective model, using unique data from the 2010 Special Module on Intrahousehold Sharing of Resources of the EU-SILC data, that allows us to define a constructed Pareto weight, which characterizes spouses' bargaining power in the household, from different survey questions about decision-making in the household. Labor supply estimates reject the traditional unitary model of the household, and the results are in line with the predictions of the collective model, since the rational collectivity hypothesis is not rejected. Furthermore, the theoretically derived sharing rule of household income suggests that Spanish wives behave more altruistically, while husbands behave more egoistically. Estimates of the constructed Pareto weight are qualitatively robust to estimates of the theoretical sharing rule, which provides direct evidence in favor of the collective model (Chiappori, 1988, 1992). Concluding that the collective model accurately captures how spouses' unobserved bargaining power and intrahousehold allocations respond to household observed attributes is the main contribution of the analysis, complementing the limited existing research that has provided direct evidence supporting the collective model (e.g., Bargain et al., 2018, for Bangladesh).

The analysis has certain limitations. For instance, the data we use is cross-sectional, so the results represent conditional correlations and are subject to unobserved heterogeneity. Estimates may suffer from reverse causality, and the correlation between work hours on one hand, and earnings or non-labor income on the other, may suffer from spurious correlations. Unfortunately, we could not determine a proper instrumentation to address this issue using the information in the EU-SILC data. Thus, no causal links are estimated in this paper, and the results should be interpreted with caution. Third, the analysis is static, which prevents us from deriving dynamic results on the response of spouses to changes in the economic environment. Further research should address these limitations using panel data bases, which could help to analyze both causal links between hours and wages, and the evolution of intrahousehold allocation of resources (Mazzocco, 2007). However, it should be noted that the empirical estimation of household collective models requires specific information to be collected in surveys, namely information on both spouses' hours of work, wages or earnings, household non-labor income, and additional variables required by the specific context in which the models are proposed. Thus, analyzing the dynamics of household bargaining power in such a context represents a challenge (Chiappori \& Mazzocco, 2017).

Despite these limitations, this paper addresses one of the main shortcomings of empirical collective models. Specifically, the collective model aims to recover unobservable economic behavior (e.g., how spouses allocate resources, wealth, and/or household income between them), from an observed behavior (spouses labor supply). Even if the theory 
establishes a link between labor supply and intrahousehold behavior, in general we cannot observe intrahousehold allocations, and then it is unclear whether or not the final conclusions obtained by household collective models of labor supply are accurate. The results in this paper allow us to conclude that collective models indeed accurately capture household unobserved economic behaviors.

Some practical conclusions may be derived from the analysis that could be considered by planners and policy makers. First, the collective model appears to be an accurate tool with which to represent intrahousehold unobserved allocation of resources from household observed behaviors (in this case, labor supply). The model could be used to evaluate different policies affecting households, such as cash transfers, or policies to alleviate poverty. For instance, it is not straightforward to determine who should receive these transfers (the husband, the wife, or the household as a unit), and the collective model may help to anticipate which option could be optimal. Second, the results suggest that intrahousehold behavior is not symmetric, as wives behave altruistically (they share a higher proportion of their extra income than the proportion they keep for themselves), while husbands behave egoistically (they exhibit exactly the opposite behav-

Fig. 1 Scree plot. The sample (EU-SILC 2010 module on intrahousehold sharing of resources) has been restricted to working spouses (married and unmarried) are assumed to cooperate, the potential formation of family units could be analyzed in this context (e.g., the formation of households could be linked to intrahousehold allocations, producing an increase in spouses' welfare, and reducing inequality). Similarly, the dissolution of family units may be the potential outcome when households do not behave collectively and spouses no longer want to cooperate, or when the household process increases intrahousehold inequality; this could then be reflected in and anticipated by changes in household labor supply.

\section{Appendix}

See Fig. 1 and Tables 4 and 5.

Funding Open Access funding provided thanks to the CRUE-CSIC agreement with Springer Nature. This work was supported by the Gobierno de Aragón [Project S32_20R, funded by Program FSE Aragón 2014-2020], and by the Spanish Ministry of Science and Innovation [Project PID2019-108348RA-I00, funded by MCIN/ AEI/10.13039/501100011033].

\section{Declarations}

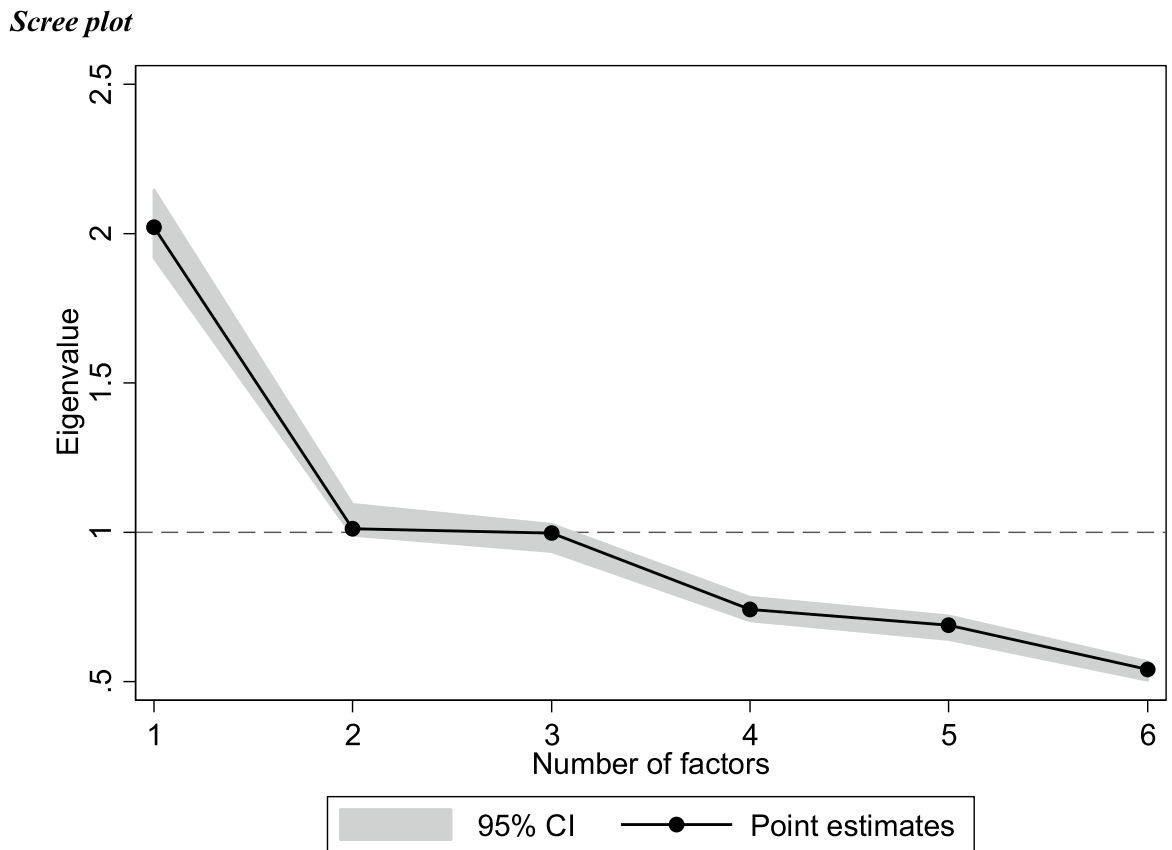

ior). Politicians and researchers should take this difference into account when measuring inequality and work-family conflict (García et al., 2007; Molina, 2021), as intrahousehold inequality, which is often ignored, may partially arise from the differential behaviors of women and men. Third, the analysis may shed light on closely related topics, such as household formation and/or dissolution. Given that spouses
Conflicts of interest The authors declare that they have no conflict of interests.

Availability of Data and Material Available upon request.

Code Availability Available upon request. 
Table 4 PCA: Constructed bargaining power

\begin{tabular}{ll}
\hline Variables & $(1)$ \\
& Loadings \\
\hline 1. Decision-making on every day shopping & 0.222 \\
2. Decision-making on durables and furniture & 0.438 \\
3. Decision-making on borrowing money & 0.499 \\
4. Decision-making on use of savings & 0.520 \\
5. Decision-making general & 0.486 \\
6. Ability to decide about own expenses & 0.026 \\
Bartlett sphericity test $p$-value & $<0.001$ \\
KMO & 0.813 \\
Variance explained & 0.517 \\
Eigenvalue & 2.081 \\
Observations & 2726
\end{tabular}

The sample (EU-SILC 2010 module on intrahousehold sharing of resources) has been restricted to working spouses (married and unmarried). All the initial variables take values 1 ("more me"), 0 ("balanced"), and -1 ("more my partner"), and are defined exclusively for wives to represent wife bargaining power (e.g., the Pareto weight $\mu$ )

Table 5 Additional labor supply estimates

\begin{tabular}{|c|c|c|c|c|c|c|}
\hline \multirow[t]{3}{*}{ Variables } & \multicolumn{2}{|c|}{ OLS estimates } & \multicolumn{2}{|c|}{ SUR estimates } & \multicolumn{2}{|c|}{ GMM restricted estimates } \\
\hline & (1) & (2) & (3) & (4) & (5) & (6) \\
\hline & Wives & Husbands & Wives & Husbands & Wives & Husbands \\
\hline Wife log-earnings & $\begin{array}{l}0.738 \\
(1.204)\end{array}$ & $\begin{array}{l}-2.700^{* * *} \\
(0.922)\end{array}$ & $\begin{array}{l}0.756 \\
(0.728)\end{array}$ & $\begin{array}{l}-2.690^{* * * *} \\
(0.617)\end{array}$ & $\begin{array}{l}0.251 \\
(0.719)\end{array}$ & $\begin{array}{l}-2.706^{* * *} \\
(0.591)\end{array}$ \\
\hline Husband log-earnings & $\begin{array}{l}-4.157^{* * * *} \\
(1.109)\end{array}$ & $\begin{array}{l}-1.570 \\
(0.859)\end{array}$ & $\begin{array}{l}-4.147^{* * * *} \\
(0.661)\end{array}$ & $\begin{array}{l}-1.568 \text { ** } \\
(0.562)\end{array}$ & $\begin{array}{l}-5.074 * * * \\
(0.635)\end{array}$ & $\begin{array}{l}-2.333^{* * * *} \\
(0.533)\end{array}$ \\
\hline Family income & $\begin{array}{l}-0.008 \\
(0.014)\end{array}$ & $\begin{array}{l}0.034^{*} \\
(0.015)\end{array}$ & $\begin{array}{l}-0.007 \\
(0.012)\end{array}$ & $\begin{array}{l}0.033^{* * * *} \\
(0.010)\end{array}$ & $\begin{array}{l}0.020 \\
(0.012)\end{array}$ & $\begin{array}{l}0.043 * * * \\
(0.010)\end{array}$ \\
\hline Cross log-earnings & $\begin{array}{l}1.167^{* * * *} \\
(0.357)\end{array}$ & $\begin{array}{l}0.399 \\
(0.289)\end{array}$ & $\begin{array}{l}1.165^{* * * *} \\
(0.234)\end{array}$ & $\begin{array}{l}0.393 * * \\
(0.199)\end{array}$ & $\begin{array}{l}1.176^{* * * *} \\
(0.226)\end{array}$ & $\begin{array}{l}0.417 * * \\
(0.193)\end{array}$ \\
\hline Wife share of family income & $\begin{array}{l}14.245^{*} \\
(5.731)\end{array}$ & $\begin{array}{l}-5.659 \\
(4.567)\end{array}$ & $\begin{array}{l}14.200^{* * * *} \\
(4.198)\end{array}$ & $\begin{array}{l}-5.602 \\
(3.576)\end{array}$ & $\begin{array}{l}6.433 \\
(4.210)\end{array}$ & $\begin{array}{l}-2.281 \\
(p=0.094)\end{array}$ \\
\hline Sex ratio & $\begin{array}{l}-0.641 \\
(0.351)\end{array}$ & $\begin{array}{l}-0.147 \\
(0.270)\end{array}$ & $\begin{array}{l}-0.642^{*} \\
(0.279)\end{array}$ & $\begin{array}{l}-0.152 \\
(0.238)\end{array}$ & $\begin{array}{l}-0.777 * * \\
(0.283)\end{array}$ & $\begin{array}{l}-0.276 \\
(p=0.215)\end{array}$ \\
\hline Age & $\begin{array}{l}-0.054 \\
(0.060)\end{array}$ & $\begin{array}{l}-0.035 \\
(0.042)\end{array}$ & $\begin{array}{l}-0.055 \\
(0.042)\end{array}$ & $\begin{array}{l}-0.035 \\
(0.033)\end{array}$ & $\begin{array}{l}-0.057 \\
(0.042)\end{array}$ & $\begin{array}{l}-0.027 \\
(0.032)\end{array}$ \\
\hline Secondary education & $\begin{array}{l}0.110 \\
(0.724)\end{array}$ & $\begin{array}{l}-0.128 \\
(0.532)\end{array}$ & $\begin{array}{l}-0.082 \\
(0.505)\end{array}$ & $\begin{array}{l}-0.150 \\
(0.396)\end{array}$ & $\begin{array}{l}-0.118 \\
(0.510)\end{array}$ & $\begin{array}{l}-0.267 \\
(0.397)\end{array}$ \\
\hline University education & $\begin{array}{l}-0.322 \\
(0.709)\end{array}$ & $\begin{array}{l}-1.986^{* * * *} \\
(0.514)\end{array}$ & $\begin{array}{l}-0.420 \\
(0.504)\end{array}$ & $\begin{array}{l}-1.852^{* * * *} \\
(0.395)\end{array}$ & $\begin{array}{l}-0.939^{*} \\
(0.501)\end{array}$ & $\begin{array}{l}-1.564 * * * \\
(0.393)\end{array}$ \\
\hline Number of children & $\begin{array}{l}0.672^{*} \\
(0.331)\end{array}$ & $\begin{array}{l}-0.308 \\
(0.336)\end{array}$ & $\begin{array}{l}0.669^{*} \\
(0.286)\end{array}$ & $\begin{array}{l}-0.304 \\
(0.243)\end{array}$ & $\begin{array}{l}0.386 \\
(0.273)\end{array}$ & $\begin{array}{l}-0.378 \\
(0.229)\end{array}$ \\
\hline Married couple & $\begin{array}{l}-0.959 \\
(0.743)\end{array}$ & $\begin{array}{l}0.590 \\
(0.605)\end{array}$ & $\begin{array}{l}-0.964 \\
(0.536)\end{array}$ & $\begin{array}{l}0.591 \\
(0.455)\end{array}$ & $\begin{array}{l}-1.014 \\
(0.577)\end{array}$ & $\begin{array}{l}0.483 \\
(0.484)\end{array}$ \\
\hline Length of marriage & $\begin{array}{l}0.023 \\
(0.056)\end{array}$ & $\begin{array}{l}0.040 \\
(0.043)\end{array}$ & $\begin{array}{l}0.023 \\
(0.039)\end{array}$ & $\begin{array}{l}0.042 \\
(0.032)\end{array}$ & $\begin{array}{l}0.031 \\
(0.039)\end{array}$ & $\begin{array}{l}0.049 \\
(0.031)\end{array}$ \\
\hline Constant & $\begin{array}{l}104.209^{* *} \\
(36.837)\end{array}$ & $\begin{array}{l}66.041 * \\
(27.928)\end{array}$ & $\begin{array}{l}104.394 \text { *** } \\
(28.617)\end{array}$ & $\begin{array}{l}66.496^{* *} \\
(24.376)\end{array}$ & $\begin{array}{l}121.566^{* * * *} \\
(29.180)\end{array}$ & $\begin{array}{l}80.496^{* *} \\
(17.919)\end{array}$ \\
\hline Region F.E & Yes & Yes & Yes & Yes & Yes & Yes \\
\hline Observations & 2726 & 2726 & 2726 & 2726 & 2726 & 2726 \\
\hline
\end{tabular}

Robust standard errors in parentheses. The sample (EU-SILC 2010 module on intrahousehold sharing of resources) has been restricted to working spouses (married and unmarried). The dependent variables are spouses' log-weekly work hours

$* p<0.05 . * * p<0.01 . * * * p<0.001$ 
Open Access This article is licensed under a Creative Commons Attribution 4.0 International License, which permits use, sharing, adaptation, distribution and reproduction in any medium or format, as long as you give appropriate credit to the original author(s) and the source, provide a link to the Creative Commons licence, and indicate if changes were made. The images or other third party material in this article are included in the article's Creative Commons licence, unless indicated otherwise in a credit line to the material. If material is not included in the article's Creative Commons licence and your intended use is not permitted by statutory regulation or exceeds the permitted use, you will need to obtain permission directly from the copyright holder. To view a copy of this licence, visit http://creativecommons.org/licenses/by/4.0/.

\section{References}

Aguiar, M., \& Hurst, E. (2007). Measuring trends in leisure: The allocation of time over five decades. Quarterly Journal of Economics, 122(3), 969-1006. https://doi.org/10.1162/qjec.122.3.969

Akerlof, G. A., \& Kranton, R. E. (2010). Identity economics. Princeton University Press.

Akerlof, G. A., \& Kranton, R. E. (2000). Economics and identity. Quarterly Journal of Economics, 115(3), 715-753. https://doi. org/10.1162/003355300554881

Attanasio, O. P., \& Lechene, V. (2014). Efficient responses to targeted cash transfers. Journal of Political Economy, 122(1), 178-222. https://doi.org/10.1086/674968

Bargain, O., Lacroix, G., \& Tiberti, L. (2018). Validating the collective model of household consumption using direct evidence on sharing. Partnership for Economic Policy Paper. https://doi.org/ $10.2139 /$ ssrn. 3264635

Bargain, O., \& Moreau, N. (2013). The impact of tax-benefit reforms on labor supply in a simulated Nash-bargaining framework. Journal of Family and Economic Issues, 34(1), 77-86. https://doi.org/ 10.1007/s10834-012-9300-9

Beblo, M., Beninger, D., \& Laisney, F. (2007). Welfare analysis of a tax reform for Germany: A comparison of the unitary and collective models of household labour supply. Journal of Population Economics, 20(4), 869-893. https://doi.org/10.1007/ s00148-006-0077-8

Becker, G. S. (1991). A treatise on the family. Harvard University Press.

Beninger, D., Bargain, O., Beblo, M., Blundell, R., Carrasco, R., Chiuri, M. C., Laisney, F., Lechene, V., Longobardi, E., Moreau, N., Myck, M., Ruiz-Castillo, J., \& Vermeulen, F. (2006). Evaluating the move to a linear tax system in Germany and other European countries. Review of Economics of the Household, 4(2), 159-180. https://doi.org/10.1007/s11150-006-0004-5

Bergstrom, T. C. (1997). A Survey of Theories of the Family. Handbook of Population and Family Economics, 1, 21-79. https://doi. org/10.1016/S1574-003X(97)80019-0

Bettinelli, C., Sciascia, S., Randerson, K., \& Fayolle, A. (2017). Researching entrepreneurship in family firms. Journal of Small Business Management, 55(4), 506-529. https://doi.org/10.1111/ jsbm. 12347

Blundell, R. W., Chiappori, P. A., \& Meghir, C. (2005). Collective labor supply with children. Journal of Political Economy, 113(6), 1277-1306. https://doi.org/10.1086/491589

Blundell, R. W., Chiappori, P. A., Magnac, T., \& Meghir, C. (2007). Collective labour supply: Heterogeneity and non-participation. Review of Economic Studies, 74(2), 417-445. https://doi.org/10. 1111/j.1467-937X.2007.00440.x

Browning, M., Bourguignon, F., Chiappori, P. A., \& Lechene, V. (1994). Income and outcomes: A structural model of intrahousehold allocation. Journal of Political Economy, 102(6), 1067-1096. https://doi.org/10.1086/261964

Browning, M., \& Chiappori, P. A. (1998). Efficient intra-household allocations: A general characterization and empirical tests. Econometrica, 66(6), 1241-1278. https://doi.org/10.2307/2999616

Browning, M., Chiappori, P. A., \& Lewbel, A. (2013). Estimating consumption economies of scale, adult equivalence scales, and household bargaining power. Review of Economic Studies, 80(4), 1267-1303. https://doi.org/10.1093/restud/rdt019

Browning, M., Chiappori, P. A., \& Weiss, Y. (2014). Economics of the Family. Cambridge University Press.

Campaña, J. C., Giménez-Nadal, J. I., \& Molina, J. A. (2018). Efficient labor supply for Latin families: Is the intra-household bargaining power relevant? IZA Discussion Paper 11695. Retrieved from https://ssrn.com/abstract=3234218

Carta, F., \& De Philippis, M. (2018). You've come a long way, baby: Husbands' commuting time and family labour supply. Regional Science and Urban Economics, 69(1), 25-37. https://doi.org/10. 1016/j.regsciurbeco.2017.12.004

Cherchye, L., De Rock, B., \& Vermeulen, F. (2012). Married with children: A collective labor supply model with detailed time use and intrahousehold expenditure information. American Economic Review, 102(7), 3377-3405. https://doi.org/10.1257/aer.102.7. 3377

Cherchye, L., De Rock, B., Lewbel, A., \& Vermeulen, F. (2015). Sharing rule identification for general collective consumption models. Econometrica, 83(5), 2001-2041. https://doi.org/10.3982/ECTA1 0839

Cherchye, L., \& Vermeulen, F. (2008). Nonparametric analysis of household labor supply: Goodness of fit and power of the unitary and the collective model. Review of Economics and Statistics, 90(2), 267-274. https://doi.org/10.1162/rest.90.2.267

Chiappori, P. A. (1988). Rational household labor supply. Econometrica, 56(1), 63-90. https://doi.org/10.2307/1911842

Chiappori, P. A. (1992). Collective labor supply and welfare. Journal of Political Economy, 100(3), 437-467. https://doi.org/10.1086/ 261825

Chiappori, P. A. (2020). The theory and empirics of the marriage market. Annual Review of Economics, 12, 547-578. https://doi.org/ 10.1146/annurev-economics-012320-121610

Chiappori, P. A., Fortin, B., \& Lacroix, G. (2002). Marriage market, divorce legislation, and household labor supply. Journal of Political Economy, 110(1), 37-72. https://doi.org/10.1086/324385

Chiappori, P. A., Giménez, J. I., Molina, J. A., Theloudis, A., \& Velilla, J. (2020). Intrahousehold commitment and intertemporal labor supply. IZA Discussion Paper 13545. Retrieved from https://ssrn. com/abstract $=3665105$

Chiappori, P. A., \& Mazzocco, M. (2017). Static and intertemporal household decisions. Journal of Economic Literature, 55(3), 985-1045. https://doi.org/10.1257/jel.20150715

Chiappori, P. A., \& Meghir, C. (2015). Intrahousehold inequality. Handbook of Income Distribution, 2, 1369-1418. https://doi.org/ 10.1016/B978-0-444-59429-7.00017-0

Chiappori, P. A., \& Meghir, C. (2021). Household Labor Economics. Edward Elgar Publishing. https://doi.org/10.4337/9781789903 546

Chiappori, P. A., \& Naidoo, J. (2020). The Engel curves of non-cooperative households. The Economic Journal, 130(627), 653-674. https://doi.org/10.1093/ej/uez069

Chiappori, P. A., \& Weiss, Y. (2007). Divorce, remarriage and child support. Journal of Labor Economics, 25(1), 37-74. https://doi. org/10.1086/508731

Cochard, F., Couprie, H., \& Hopfensitz, A. (2018). What if women earned more than their spouses? An experimental investigation of work-division in couples. Experimental Economics, 21(1), 50-71. https://doi.org/10.1007/s10683-017-9524-5 
Crespo, L. (2009). Estimation and testing of household labour suply models: Evidence from Spain. Investigaciones Económicas, 33(2), 303-335.

Donni, O. (2007). Collective female labour supply: Theory and application. The Economic Journal, 117(516), 94-119. https://doi.org/10. 1111/j.1468-0297.2007.02003.x

Donni, O., \& Chiappori, P. A. (2011). Nonunitary models of household behavior: A survey of the literature. In J. A. Molina (Ed.), Household economic behaviors (pp. 1-40). Springer.

Donni, O., \& Matteazzi, E. (2012). On the importance of household production in collective models: Evidence from US data. Annals of Economics and Statistics, 105(106), 99-125. https://doi.org/ $10.2307 / 23646458$

Donni, O., \& Matteazzi, E. (2018). Collective decisions, household production, and labor force participation. Journal of Applied Econometrics, 33(7), 1064-1080. https://doi.org/10.1002/jae.2652

Donni, O., \& Molina, J. A. (2018). Household collective models: Three decades of theoretical contributions and empirical evidence. IZA Discussion Paper 11915. Retrieved from https://ssrn.com/abstr act $=3286175$

Donni, O., \& Moreau, N. (2007). Collective labor supply: A singleequation model and some evidence from French data. Journal of Human Resources, 42(1), 214-246. https://doi.org/10.3368/jhr. XLII.1.214

Duflo, E. (2003). Grandmothers and granddaughters: Old-age pensions and intrahousehold allocation in South Africa. World Bank Economic Review, 17(1), 1-25. https://doi.org/10.1093/wber/lhg013

Dunbar, G. R., Lewbel, A., \& Pendakur, K. (2013). Children's resources in collective households: Identification, estimation, and an application to child poverty in Malawi. American Economic Review, 103(1), 438-471. https://doi.org/10.1257/aer.103.1.438

European Commission (2010). 2010 EU-SILC module on intra-household sharing of resources: Assessment of the implementation. European Commission, Directorate F: Social and information society statistics, Unit F-4: Quality of life.

European Commission (2017). Methodological guidelines and description of EU-SILC target variables, 2016 operation. European Commission, DocSILC065.

García, I., Molina, J. A., \& Navarro, M. (2007). How satisfied are spouses with their leisure time? Evidence from Europe. Journal of Family and Economic Issues, 28(4), 546-565. https://doi.org/ 10.1007/s10834-007-9082-7

Gimenez-Nadal, J. I., Molina, J. A., \& Sevilla-Sanz, A. (2012). Social norms, partnerships and children. Review of Economics of the Household, 10(2), 215-236. https://doi.org/10.1007/ s11150-011-9120-y

Gimenez-Nadal, J. I., \& Sevilla, A. (2012). Trends in time allocation: A cross-country analysis. European Economic Review, 56(6), 1338-1359. https://doi.org/10.1016/j.euroecorev.2012.02.011

Giovanis, E., \& Ozdamar, O. (2019). A collective household labour supply model with disability: Evidence from Iraq. Journal of Family and Economic Issues, 40(2), 209-225. https://doi.org/10.1007/ s10834-018-9597-0

Goldin, C. (2006). The quiet revolution that transformed women's employment, education, and family. American Economic Review, 96(2), 1-21. https://doi.org/10.1257/000282806777212350

Görges, L. (2015). The power of love: A subtle driving force for unegalitarian labor division? Review of Economics of the Household, 13(1), 163-192. https://doi.org/10.1007/s11150-014-9273-6

Grossbard-Shechtman, A. (1984). A theory of allocation of time in markets for labour and marriage. The Economic Journal, 94(376), 863-882. https://doi.org/10.2307/2232300

Grossbard, S. (2014). The marriage motive: A price theory of marriage. How marriage markets affect employment, consumption, and savings. Springer.
Guiso, L., Sapienza, P., \& Zingales, L. (2006). Does culture affect economic outcomes? Journal of Economic Perspectives, 20(2), 23-48. https://doi.org/10.1257/jep.20.2.23

Hansen, L. P. (1982). Large sample properties of Generalized Method of Moments estimators. Econometrica, 50(4), 1029-1054. https:// doi.org/10.2307/1912775

Jianakoplos, N. A., \& Bernasek, A. (2008). Family financial risk taking when the wife earns more. Journal of Family and Economic Issues, 29(2), 289-306. https://doi.org/10.1007/ s10834-008-9102-2

Lien, N. H., Westberg, K., Stavros, C., \& Robinson, L. J. (2018). Family decision-making in an emerging market: Tensions with tradition. Journal of Business Research, 86, 479-489. https://doi.org/ 10.1016/j.jbusres.2017.09.003

Lim, H., Shin, S. H., Wilmarth, M. J., \& Park, N. (2021). Who decides? Financial decision-making among older couples. Journal of Family and Economic Issues. https://doi.org/10.1007/ s10834-021-09775-3

Lise, J., \& Yamada, K. (2019). Household sharing and commitment: Evidence from panel data on individual expenditures and time use. Review of Economic Studies, 86(5), 2184-2219. https://doi. org/10.1093/restud/rdy066

Lyssiotou, P. (2017). The impact of targeting policy on spouses' demand for public goods, labor supplies and sharing rule. Empirical Economics, 53(2), 853-878. https://doi.org/10.1007/ s00181-016-1134-0

Lundberg, S., \& Pollak, R. A. (1994). Noncooperative bargaining models of marriage. American Economic Review, 84(2), 132-137. Retrieved from https://www.jstor.org/stable/2117816

Lundberg, S. J., Pollak, R. A., \& Wales, T. J. (1997). Do husbands and wives pool their resources? Evidence from the United Kingdom child benefit. Journal of Human Resources, 32(3), 463-480. https://doi.org/10.2307/146179

Malone, K., Stewart, S. D., Wilson, J., \& Korsching, P. F. (2010). Perceptions of financial well-being among American women in diverse families. Journal of Family and Economic Issues, 31(1), 63-81. https://doi.org/10.1007/s10834-009-9176-5

Manser, M., \& Brown, M. (1980). Marriage and household decisionmaking: A bargaining analysis. International Economic Review, 21(1), 31-44. https://doi.org/10.2307/2526238

Mazzocco, M. (2007). Household intertemporal behavior: A collective characterization and a test of commitment. Review of Economic Studies, 74(3), 857-895. https://doi.org/10.1111/j.1467-937X. 2007.00447.x

McElroy, M. B., \& Horney, M. J. (1981). Nash-bargained household decisions: Toward a generalization of the theory of demand. International Economic Review, 22(2), 333-349. https://doi.org/ $10.2307 / 2526280$

Michaud, P. C., \& Vermeulen, F. (2011). A collective labor supply model with complementarities in leisure: Identification and estimation by means of panel data. Labour Economics, 18(2), 159167. https://doi.org/10.1016/j.labeco.2010.10.005

Molina, J. A. (2021). The work-family conflict: Evidence from the recent decade and lines of future research. Journal of Family and Economic Issues, 42(1), 4-10. https://doi.org/10.1007/ s10834-020-09700-0

Molina, J. A., Ferrer, A., Giménez-Nadal, J. I., Gracia-Lázaro, C., Moreno, Y., \& Sanchez, A. (2019). Intergenerational cooperation within the household: A Public Good game with three generations. Review of Economics of the Household, 17(2), 535-552. https://doi.org/10.1007/s11150-018-9414-4

Molina, J. A., Gimenez-Nadal, J. I. \& Velilla, J. (2018). Intertemporal labor supply: A household collective approach. IZA Discussion Paper 11276. Retrieved from https://ssrn.com/abstract=3111149

Myck, M., Bargain, O., Beblo, M., Beninger, D., Blundell, R., Carrasco, R., Chiuri, M. C., Laisney, F., Lechene, V., Longobardi, 
E., Moreau, N., Ruiz-Castillo, J., \& Vermeulen, F. (2006). The working families' tax credit and some European tax reforms in a collective setting. Review of Economics of the Household, 4(2), 129-158. https://doi.org/10.1007/s11150-006-0003-6

Pronzato, C. (2017). Decisiones sobre fecundidad y tipos de cuidado infantil alternativos. IZA World of Labor. https://doi.org/10.15185/ izawol.382

Radchenko, N. (2016). Welfare sharing within households: Identification from subjective well-being data and the collective model of labor supply. Journal of Family and Economic Issues, 37(2), 254-271. https://doi.org/10.1007/s10834-015-9446-3

Rapoport, B., Sofer, C., \& Solaz, A. (2011). Household production in a collective model: Some new results. Journal of Population Economics, 24(1), 23-45. https://doi.org/10.1007/s00148-010-0308-x

Thomas, D. (1990). Intra-household resource allocation: An inferential approach. Journal of Human Resources, 25(4), 635-664. https:// doi.org/10.2307/145670

Velilla, J. (2020). Testing the sharing rule in a collective model of discrete labor supply with Spanish data. Applied Economics Letters, 27(10), 848-853. https://doi.org/10.1080/13504851.2019. 1646401
Vermeulen, F. (2005). And the winner is... An empirical evaluation of unitary and collective labour supply models. Empirical Economics, 30(3), 711-734. https://doi.org/10.1007/s00181-005-0258-4

Vermeulen, F. (2006). A collective model for female labour supply with non-participation and taxation. Journal of Population Economics, 19(1), 99-118. https://doi.org/10.1007/s00148-005-0007-1

Yilmazer, T., \& Lyons, A. C. (2010). Marriage and the allocation of assets in women's defined contribution plans. Journal of Family and Economic Issues, 31(2), 121-137. https://doi.org/10.1007/ s10834-010-9191-6

Yusof, S. A., \& Duasa, J. (2010). Consumption patterns and income elasticities in Malaysia. Malaysian Journal of Economic Studies, 47(2), 91-106.

Publisher's Note Springer Nature remains neutral with regard to jurisdictional claims in published maps and institutional affiliations. 